\title{
Effect of Collaborative Care System (CCS) on Blood Glucose Levels in Type 2 Diabetes Mellitus Outpatient
}

\author{
Nuryati Kuman, Bangunawati Rahajeng \\ School of Pharmacy Faculty of Medicine and Health Sciences \\ University of Muhammadiyah Yogyakarta, Yogyakarta, Indonesia
}

\begin{abstract}
Some health system in various countries in the world is highly fragmented and is unable to resolve health problems. With collaborative care system, it is expected that DM patients can be managed well. We conducted a study to determine the effect of collaborative care system on blood glucose levels of patients with type 2 diabetes mellitus. This study uses a quasi-experimental design. Data was obtained by measuring random blood glucose levels in patients with type 2 diabetes mellitus. The samples consisted of 66 diabetic patients divided into 2 groups: 35 patients in the intervention group in Puskesmas Fakfak and 31 patients in the control group in Balai Pengobatan Misi. Data was analyzed using statistical paired sample $t$ test in the intervention group, the Wilcoxon test for the control group, and the Mann-Whitney test to compare the difference of random blood glucose levels between the groups. The results showed that the collaborative care system in the intervention group for 1 month shows the average random blood glucose levels before CCS $276.11 \mathrm{mg} / \mathrm{dL}$ and after CCS $222.43 \mathrm{mg} / \mathrm{dL}$. Whereas in the control group before CCS $217.32 \mathrm{mg} / \mathrm{dL}$ and after CCS $266.45 \mathrm{mg} / \mathrm{dL}$. Statistical test result showed significant differences $(p<0.05)$ between random blood glucose levels before and after the CCS in the intervention group and the control group The conclusion of this study is a collaborative care system affects the reduction in random blood glucose levels in patients with type 2 diabetes mellitus.
\end{abstract}

Key words: Collaborative Care System (CCS), diabetes mellitus type 2, random blood glucose level

\section{Pengaruh Collaborative Care System (CCS) terhadap Kadar Glukosa Darah Pasien Rawat Jalan dengan Penyakit Diabetes Melitus Tipe 2}

\begin{abstract}
Abstrak
Beberapa sistem kesehatan di berbagai negara di dunia sangat terfragmentasi dan tidak dapat menyelesaikan masalah kesehatan. Dengan sistem collaborative care, diharapkan pasien diabetes melitus (DM) dapat dikelola dengan baik. Penelitian ini dilakukan untuk mengetahui pengaruh sistem collaborative care pada kadar glukosa darah pasien DM tipe 2. Penelitian ini menggunakan desain quasi-eksperimental. Data diperoleh dengan mengukur kadar glukosa darah sewaktu pada pasien dengan DM tipe 2. Sampel terdiri dari 66 pasien DM yang dibagi menjadi 2 kelompok, yaitu 35 pasien pada kelompok intervensi di Puskesmas Fakfak dan 31 pasien dalam kelompok kontrol di Balai Pengobatan Misi. Data dianalisis dengan menggunakan uji statistik paired sample $t$ test pada kelompok intervensi, uji Wilcoxon untuk kelompok kontrol, dan uji Mann-Whitney untuk membandingkan perbedaan kadar glukosa darah sewaktu antar kelompok. Hasil penelitian menunjukkan bahwa sistem collaborative care pada kelompok intervensi yang dilakukan selama 1 bulan menunjukkan kadar glukosa darah sewaktu rata-rata sebelum SCC adalah 276,11 mg/dL dan setelah SCC adalah 222,43 mg/dL. Pada kelompok kontrol sebelum SCC adalah 217,32 mg/dL dan setelah SCC adalah 266,45 mg/dL. Hasil uji statistik menunjukkan perbedaan yang signifikan $(\mathrm{p}<0,05)$ antara kadar glukosa darah sewaktu sebelum dan sesudah SCC pada kelompok intervensi dan kelompok kontrol. Sistem collaborative care memengaruhi penurunan kadar glukosa darah acak pada pasien dengan DM tipe 2.
\end{abstract}

Kata kunci: Collaborative Care System (CCS), diabetes melitus tipe 2, kadar glukosa darah sewaktu

Corresspondence: Bangunawati Rahajeng, M.Si., Apt., School of Pharmacy Faculty of Medicine and Health Sciences University of Muhammadiyah Yogyakarta, Yogyakarta, Indonesia, email: brahajeng@yahoo.com Received: 17 $7^{\text {th }}$ September 2015, Accepted: $10^{\text {th }}$ January 2016, Published: $1^{\text {st }}$ March 2016 


\section{Introduction}

Diabetes Mellitus (DM) is a collection of metabolic diseases that characterized by hyperglycemia due to a lack of insulin secretion, insulin action or both. ${ }^{1}$ Epidemiologically, it indicates a trend of the increase in the incidence and prevalence of DM in different corners of the world. WHO predicts the increase number of people with diabetes in Indonesia from 8.4 million in 2000 to about 21.3 million in 2030. Similar to WHO, the International Diabetes Federation (IDF) in 2009, predicted a rise in the number of people with diabetes from 7.0 million in 2009 to 12.0 million in 2030. Although there are differences in the prevalence rate, both reports showed an increase in the number of people with diabetes by $2-3$ fold in $2030 .^{2}$

Report the results of Health Research (Riskesdas) in 2007 by the Ministry of Health show that the prevalence of impaired glucose tolerance (IGT), ranging between $4.0 \%$ in the provinces of Jambi and the highest $21.8 \%$ in the province of West Papua. ${ }^{3}$ Based on data from the International Diabetes Federation (IDF) in 2011, there were 329 million people worldwide suffering from type 2 diabetes with mortality rates reaching 4.6 million people. In 2011 Indonesia was ranked the world's tenth of people with type 2 diabetes mellitus as many as 6.6 million people and by 2030 is projected to occupy the ninth position with the estimation as many as 10.6 million people with diabetes. ${ }^{4}$

These data indicate that the number of people with diabetes, especially type 2 in Indonesia is very large and becomes heavy burden to handle by a specialist/subspesialist, even by all existing health workers. In general, patients with diabetes are not getting optimal care, so that the blood glucose levels are not well controlled. This issue provides an opportunity for pharmacists to contribute in the treatment of patients' with diabetes.
According to The National Community Pharmacists Association's National Institute for Pharmacist Care Outcomes in the USA, the contribution of pharmacists focuses on prevention and improvement of diseases, including identifying and assessing the health of the patient, monitoring, evaluating, educating and counseling, interventing, and completing therapy associated with medication to improve services to patients. Pharmacist's contribution is the part of disease management, meaning that it includes pharmacological and nonpharmacological therapy.

Collaborative care is an intervention system at the level health services using case management to link primary care providers with patient. The form of collaborative care is to merge three health cares, namely medical care, pharmaceutical care, and nurse care. The three services are expected to be continued with each other in order to achieve the objectives in the management of patients by emphasizing the shared responsibility in the management of patient care. Bilateral decision-making process that is based on education and the ability of the practitioner, so that health professionals (doctors, nurses and pharmacists) can carry out their duties and responsibilities in accordance with the standards of competence of each profession and avoid conflicts of health personnel in the management of patients. ${ }^{5}$

The implementation of collaborative care in primary care centers become important because primary care centers are often responsible for managing diabetic patients and are well positioned to provide integrated services in improving the physical and mental condition. ${ }^{6}$

\section{Methods}

The study was conducted in Fakfak Health Center (Puskesmas Fakfak) and Balai 
Pengobatan Misi Kabupaten Fakfak West Papua in August-September 2014. The tools and materials used in the study were the leaflets which contained the definition of DM, DM causes, symptoms of diabetes, the diagnosis of diabetes and complications; CD containing DM gymnastics, gymnastics legs $\mathrm{DM}$, and extension materials; guide books of collaborative care that is used as a guide for physicians, pharmacists and nurses on patient intervention; control card used by the patient during the study; pin used by the collaborative care team and patient in intervention group as identification; Informed consent used to maintain a commitment during the study.

Patients whobecame research subjects were patients with type 2 diabetes who became out patients at Puskesmas Fakfak (intervention group) and at Balai Pengobatan Misi (control group). All subjects in both groups of samples submitted inclusion criteria were briefed and informed consent charge sheet then measured a random blood glucose levels (pre-test). Intervention group (patients in Puskesmas Fakfak) treated three times per week for three weeks. Intervention such as collaborating care services namely counseling in the first week, routine examination in Puskesmas Fakfak in the second week, and in the third week of diabetic patients participated in gymnastics and gymnastics diabetic foot. While the control group (patients at Balai Pengobatan Misi) received services as usual (without collaborative care system).

After the activities of collaborative care system were done, at the end of the meeting the researcher conducted measurement of random blood glucose levels in the intervention group and the control group as a post test.

\section{Results}

Researchers took the data from the medical records of the 50 people with Type 2 diabetes patients in Puskesmas Fakfak. From the medical records obtained 35 people entering the inclusion criteria. The same data retrieval performed on 43 patients with Type 2 diabetes who became out patients at Balai Pengobatan Misi. A total of 31 patients entered into the inclusion criteria and were taken as a control group. Prior to the intervention, subjects in both groups were given a pretest of the examination of random blood glucose levels. Then the intervention group was treated with Collaborative Care System in accordance guidebooks Collaborative Care for \pm 1 month started in August-September 2014. The control group was not given the same treatment as the intervention group. After that, there was the form of post test measurement of random blood glucose levels to both groups.

Subject characteristics of Collaborative Care System Group (CCS) and control group is shown in Table 1. Among 35 respondents in the CCS group, the reseracher found that most patients were in the age group the range of 43 to 65 years and for a control group of 31 respondents, age range from 44 up to 64 years with significant value $>0.05$, which means the difference age distribution of patients was not significant between the intervention group and the control group.

Table 1 Comparison of Characteristics of CCS and Control Group

\begin{tabular}{lccc}
\hline \multicolumn{1}{c}{ Characteristics } & CCS group $(\mathbf{N}=\mathbf{3 5})$ & Control group $(\mathbf{N}=\mathbf{3 1})$ & Sig. \\
\hline Age (years) & $54.03 \pm 10853$ & $54.35 \pm 9767$ & 0.889 \\
Gender $(\%)$ & & & \\
Man & 22.9 & 42.9 & \\
Woman & 77.1 & 45.7 & \\
\hline
\end{tabular}


Table 2 Pairwise Test Analysis Random Blood Glucose Levels of Intervention Group

\begin{tabular}{cccc}
\hline $\begin{array}{c}\text { Pre test } \\
(\mathbf{m g} / \mathbf{d L})\end{array}$ & $\begin{array}{c}\text { Post test } \\
(\mathbf{m g} / \mathbf{d L})\end{array}$ & $\begin{array}{c}\text { Total Value Random Blood Glucose } \\
\text { Levels pre and post after CCS (mg/dL) }\end{array}$ & Value 2 Sig. \\
\hline $276.11 \pm 101.00$ & $222.43 \pm 77.67$ & -53.68 & 0,000 \\
\hline
\end{tabular}

By sex, the intervention group consisted of $77.1 \%$ women and $22.9 \%$ of men, while the control group there were $45.7 \%$ women and $42.9 \%$ of men with significant value $<0.05$, which means differences in the proportion of sexes patients significantly between the intervention group and the control group. This is because the subjects taken as the samples were all patients of Puskesmas Fakfak and Balai Pengobatan Misi who had met the inclusion criteria. From the total respondents, 66 respondents, the tendency of women suffering from diabetes is greater than man.

The analysis of effect of collaborative care system against blood glucose levels is shown in Table 2. Statistical analysis results were then tested using normality test and the results normally distributed data with significant value $>0.05$. Then performed statistical tests using Paired Sample T Test and gained an average of random blood glucose levels as prior to collaborative care system $276.11 \pm 101.00 \mathrm{mg} / \mathrm{dl}$ and after the collaborative care system gained $222.43 \pm 77.67 \mathrm{mg} / \mathrm{dL}$, In table 2 it can be seen that the average value of the random blood glucose levels seen mathematically decreased by $53 \mathrm{mg} / \mathrm{dL}$. When tested using statistical test obtained significance value of 0.000 (Table 2) which means there is a significant reduction in the value of the random blood glucose levels before the patient is provided with a collaborative care system and after given a collaborative care system. Statistics test results to know the difference random blood glucose levels of patient control group is shown in Table 3.

From the data obtained by the statistical test, it was not normally distributed with a significance value $<0.05$. Because the data obtained were not normally distributed then used a statistical the Wilcoxon test and gained an average of random blood glucose levels the control group of patients was $217.32 \pm 95.50 \mathrm{mg} / \mathrm{dL}$ and $266.45 \pm 111.32 \mathrm{mg} /$ $\mathrm{dL}$, Table 3 shows that the levels of random blood glucose levels in the control group shown mathematically increased by $49 \mathrm{mg} /$ dl. Then, by using a statistical test, it obtained significant value of 0.003 (Table 3), which means that there was a significant increase in random blood glucose levels pre and post in the control group of patients without a collaborative care system.

This study used a quasi-experimental design, where the subjects were subjected to two times before and after the measurement. Shown in Table 2 and Table 3, before the intervention group was given a collaborative care system obtained random blood glucose levels of $276.11 \pm 101.00 \mathrm{mg} / \mathrm{dL}$ and after given a collaborative care system for $222.43 \pm 77.67$ $\mathrm{mg} / \mathrm{dl}$ and in the control group random blood glucose levels obtained before $217.32 \pm 95.50$ $\mathrm{mg} / \mathrm{dl}$ and after $266.45 \pm 111.32 \mathrm{mg} / \mathrm{dL}$. Data obtained from tests of normality were not

Table 3 Analysis Wilcoxon Test Random Blood Glucose Levels of Control Group

\begin{tabular}{cccc}
\hline $\begin{array}{c}\text { Pre test } \\
(\mathbf{m g} / \mathbf{d l})\end{array}$ & $\begin{array}{c}\text { Post test } \\
(\mathbf{m g} / \mathbf{d L})\end{array}$ & $\begin{array}{c}\text { Total Value Random Blood Glucose } \\
\text { Levels pre and post after CCS (mg/dL) }\end{array}$ & Value 2 Sig. \\
\hline $217.32 \pm 95.50$ & $266.45 \pm 111.32$ & +49.13 & 0.003 \\
\hline
\end{tabular}


normally distributed with significant value 0.017 . Because the data were not normally distributed, the Mann-Whitney test was used, differences in changes in random blood glucose levels demonstrated the significant value of 0.000 , so it can be concluded that there were significant differences in the levels of random blood glucose changes before and after the CCS between the intervention and control groups.

\section{Discussion}

The study lasted for 1 month. It was divided into three stages: the first stage examination of random blood glucose levels as the data prior to the intervention, the second stage of the implementation of collaborative care systems appropriate to guide collaborative care intervention group and phase measurements into three levels of random blood glucose levels as a post test. After the pre-test data obtained in the form of random blood glucose levels before the intervention in both groups later in the second week of collaborative care teams performed the treatment in the intervention group according to the guidelines of collaborative care by carrying out the 5 pillars in the management of diabetes. Having measured the random blood glucose levels, the patient was given a pin for identification collaborative patient care, in the second week following the intervention group patients were given counseling by doctors, nurses, medical students and pharmacy students.

Before counseling patients measured random blood glucose levels using a stick (EasyTouch), their blood pressure measured and distributed leaflets. Furthermore, in the third week of control patients returned to the clinic tailored to the patient's complaints, a team of collaborative care (medical students and pharmacy students) made a visit to the patient's home on demand, provided education to patients who could not follow counseling and training independent measurement of blood glucose levels. In the fourth week the intervention patients following gymnastics diabetes and diabetic foot gymnastics. Before attending gymnastics patients random blood glucose levels measured, blood pressure, and diabetes management according to the needs of each patient. In the last week the two groups both the intervention group and the control group measured random blood glucose levels as a post test.

Judging from the gender shows that the number of female patients for the intervention group $77.1 \%$ and the control group $45.7 \%$ more than the number of men in the intervention group $22.9 \%$ and the control group $42.9 \%$. These results support the theory that more women than men suffer from DM. In addition, previous researches showed that patients with type 2 diabetes was more common in women than men..$^{9,10}$ This result was also confirmed by the results of another research, that women have a chance to increase physical body mass index greater. ${ }^{11}$ Monthly cycle syndrome (premenstrual syndrome), post-menopause which makes the distribution of body fat becomes easy to accumulate as a result of the hormonal process causes women are more at risk of suffering from type 2 diabetes mellitus.

In terms of age, the age range was obtained for the intervention group 43 to 65 years and the control group between 44 up to 64 years. In developing countries the adults were at risk for type 2 diabetes on the age of 46 to 64 years. ${ }^{12}$ Type 2 diabetes usually occurs at the age where it begins an increase in glucose intolerance. The existence of the aging process causes a reduction in the ability of $\beta$-cells of the pancreas to produce insulin. Further said type 2 diabetes is a disease that occurs due to a decrease in organ function (degenerative) which is primarily a metabolic disorder of carbohydrate, fat, and protein so that the case will rise in line with age. ${ }^{12}$ 
Once the data of blood glucose levels before and after the intervention are obtained, they are analyzed to assess the effect of collaborative care system on random blood glucose levels. The first analysis was paired t-test (paired sample t-test) in the intervention group. From the data in Table 2 it can be seen that the average blood glucose levels as before and after the collaborative care system that is $276.11 \pm 101,00 \mathrm{mg} / \mathrm{dL}$ and $222.43 \pm 77,67 \mathrm{mg} /$ $\mathrm{dL}$ with a significance value of 0.000 , so it can be concluded that there is a significant reduction in random blood glucose levels before patients are given a collaborative care system and after given a collaborative care system. Patients who have a history of chronic diseases such as uncontrolled diabetes, and coronary heart disease or both have a poor prognosis and an effect on the high maintenance costs. The presence-based care management collaboration among health professionals (doctors and nurses) obtain significant results in patient intervention than in control patients, where the patients with chronic disease in the intervention group were significantly more controlled. ${ }^{8}$

A second analysis was the control group. The obtained results of the data were not normally distributed with a significance value $<0.05$. The result is an average blood glucose levels as before and after without any collaborative care system was $217.32 \pm 95.5$ $\mathrm{mg} / \mathrm{dL}$ and $266.45 \pm 111.32 \mathrm{mg} / \mathrm{dL}$ with significant value gained 0.003 (Table 3 ). Data showed 24 patients from a total of 31 control patients have elevated levels of random blood glucose post test, it could be caused by several factors related to the five pillars in the management of diabetes done in a collaborative care system that is the lack of education, diet, exercise, medication adherence and monitoring of blood glucose levels on a regular basis or measurement of blood glucose levels independently. Implementation of the 5 pillars of DM will give results in the form of blood glucose levels were controlled.

From various studies on type 2 diabetes, the known factors that influence the help the success of treatment of type 2 diabetes include:

1. Education and intensive training entitled Self Management Training. Peiber (2003) and Noris (2012) states that generally type 2 diabetes occurs when the lifestyle and behavior patterns have been firmly established, therefore the successful management of type 2 diabetes requires the active participation of patients and their families. ${ }^{13-14}$ Good educations at least include an understanding of:

a. Type 2 diabetes mellitus; etiology, pathophysiology, and clinical symptoms.

b. The importance of controlling and monitoring of diabetes mellitus type 2 .

c. Acute and chronic complications of type 2 diabetes and signs of complications.

d. Treatment programs including pharmacologic and non pharmacologic intervention.

e. Self management including metabolic monitoring (blood sugar levels, urine) and monitoring symptoms of glucose regulation and side effects of drugs.

f. Lifestyle changes, for example; quit smoking.

g. Healthy eating pattern and physical activity. ${ }^{13-14}$

2. Physical activity and exercise habits. Exercise in patients with type 2 diabetes may lead to increase the use of glucose by the active muscles, so it can directly reduce blood glucose levels. Besides beneficial for glycemic control, exercise on type 2 diabetes is also useful to reduce excessing weight and improve lipid profile, so that the development of vascular complications can be inhibited. ${ }^{15}$ 
3. Diet and meal planning, weight loss. Patients with type 2 diabetes whose diabetes diet planning with a balanced composition (carbohydrates: 55$60 \%$, protein $15-20 \%$, and fat 20 $30 \%$ apparently showed significant improvement $(p<0.01)$ on fasting plasma glucose, HbA1c, body mass index and cholesterol. ${ }^{16}$

4. Medication adherence. People who have a risk for medication adherence 4 times to be successful in the management of type 2 diabetes compared with non-adherent and statistically significant. ${ }^{15}$

5. Self Monitoring Blood Glucose. In this study measured variable is random blood glucose levels of patients. To determine differences in changes in the random blood glucose levels in the intervention group and the control group performed statistical tests using independent sample t-test. Because the data obtained were not normally distributed so that the statistical analysis using the Mann Whitney test. In the table Mann Whitney, the difference changes the random blood glucose levels before and after the CCS between the intervention and control groups seen significant value of 0.000 . Because the significance value smaller than the value of 0.05 can be concluded that there are significant differences in changes in random blood glucose levels in patients in the intervention and control groups. This shows that a collaborative care system intervention effect on the reduction in random blood glucose levels in patients with diabetes mellitus type 2 . It is consistent with the previous report. ${ }^{8}$

\section{Conclusion}

Collaborative care system affect the reduction in random blood glucose levels in patients with type 2 diabetes mellitus.

\section{Acknowledgements}

The authors thank to dr. Diana Tan as Head of Fakfak Primary Healthcare and Nurse Diana as the Head of Balai Pengobatan Misi for supporting this research. Thank to dr. Debby, dr. Irma, Awam Bahamba, and Santi as our collaborative care team. And also we would like to say thank Armita Abdulah, Apt as the pharmacist who gave patient counseling in this research.

\section{Funding}

The research was an independent research funded by members of the research team.

\section{Conflict of Interest}

The authors declared no potential conflicts of interest with respect to the research, authorship, and/or publication of this article.

\section{References}

1. American Diabetes Association (ADA). Diagnosis and classification of Diabetes Mellitus. Diabetes Care. 2010;33(1): 562-9. doi: 10.2337/dc10-S062.

2. Perkumpulan Endokrinologi Indonesia. Konsensus pengendalian dan pencegahan diabetes melitus tipe 2 di Indonesia. Jakarta: PB PERKENI; 2011

3. Riset Kesehatan Dasar Laporan Nasional 2007. Jakarta: Badan Penelitian dan Pengembangan Kesehatan Departemen Kesehatan Republik Indonesia; 2007.

4. International Diabetes Federation (IDF). Diabetes disease: time to act [accessed on 6 Mei 2014]. Available at: http://www.idf. org/webdata/docs/Diabetes $\% 20$ and $\% 20$ CVD.pdf

5. Pharmaceutical care untuk penyakit diabetes mellitus. Jakarta: Departemen Kesehatan Republik Indonesia; 2005. 
6. Riley MD. Building collaborative partnerships in primary health care (thesis). London: The University Of British; 2009.

7. World Health Organization. Definition, diagnosis and classification of diabetes mellitus and its complication. Report of a WHO consultation part I: diagnosis and classification of diabetes Mellitus. Jenewa; 2010.

8. Katon WJ, Elizabeth HBL, Korff MV. Collaborative care for patients with depression and chronic illnesses. N Eng J Med. 2010;363(27):2611-20. doi: 10.1056/NEJMoa1003955.

9. Lubis JP. Perilaku penderita diabetes melitus rawat jalan di RSUD Rantauprapat Kabupaten Labuhan Batu (skripsi). Medan: Universitas Sumatra Utara; 2012

10. Bintanah S, Handarsan E. Asupan serat dengan kadar gula darah, kadar kolesterol total dan status gizi pada pasien DM tipe 2 di Rumah Sakit Roemani Semarang. Jurnal Unimus; 2012.

11. Irawan D. Prevalensi dan faktor risiko kejadian DM Tipe 2 di daerah urban indonesia (analisa data sekunder Riskesdas 2007). Jakarta: UII Press; 2010.

12. Sujaya IN. Pola konsumsi makanan tradisional Bali sebagai faktor risiko Diabetes Melitus tipe 2 di Tabanan. Jurnal Skala Husada; 2009.

13. Pieber T. Clinical review management of type 2 diabetes. Majalah Medical Progress. 2003;30(2).

14. Noris SL, Engelgau, Narayan KM. Effectiveness of self management training in type 2 diabetes. Diabetes Care. 2001;24(3):561-87. doi: 10.2337/ diacare. 24.3.561.

15. Setyoutomo AY. Hubungan antara 4 pilar pengelolaan diabetes melitus dengan keberhasilan pengelolaan diabetes melitus tipe 2 (skripsi). Semarang: Universitas Diponegoro; 2011.

16. Jazilah, Paulus W, Sudargo T. Hubungan tingkat pengetahuan, sikap dan praktik (PSP) penderita diabetes mellitus mengenai pengelolaan diabetes mellitus dengan kendali kadar glukosa darah. Majalah Sains Kesehatan. 2003;16(3). 